\title{
What to do about European union
}

That Denmark should have thrown dust in the eyes of those working for a politically united Europe only illustrates the force of last week's argument that Europe needs ways of making decisions that command general respect.

Wно would have thought that 50,000 voters in last week's Danish referendum on the Maastricht Treaty would so easily have confused the European enterprise? Danish commentators had been saying in advance that the result would be close, but had assumed that calculations of the economic benefits of continued membership of the European Commnunities (EC) would, in the end, prevail. In the event, they did not, which is no great surprise. Uncompliant Danes could well have concluded that to vote against the treaty would leave Europe exactly as it is, without further supranational integration and without changing Denmark's status. The other 11 member governments have responded by putting their heads firmly in the sand, saying that they will press ahead with integration, hoping that Denmark will change its mind before the year is out. Meanwhile, lawyers in Brussels are touting a scheme whereby the surviving members would renounce the Treaty of Rome, and adopt Maastricht instead. The snag there is that there would have to be a rerun of the whole ratification process with a different treaty.

The moral in this muddled tale is simply that it is yet another, if almost melodramatic, proof that Europe's way of reaching decisions is cack-handed (see Nature 357, 347; 4 June 1992). So much should be clear from the way in which the final version of the treaty was put together last December, by horse-trading between heads of government. $\mathrm{Mr}$ John Major's supposed victories on behalf of Britain (that the planned move to a single currency in four years would not apply if Britain then chose otherwise, and that a raft of social legislation would be optional) now seem hollow, national derogations from a treaty that may no longer have force. What now emerges is that horse-trading may satisfy those who participate, but is not more widely persuasive.

What, in this crisis for the EC, should be done? The plain truth is that most member governments are lumbered with a substantial (if minority) army of domestic sceptics. Many of them, including both the British and the German governments, would not wish to follow Denmark in a referendum, but would rather hurry on with ratification. The President of France, on the other hand, has been forced to promise to take the risk this autumn, mostly out of fear that next year's elections to the national assembly would otherwise be compromised. The most obvious difficulty, then and now, is that the people of Europe know too little about the treaty and its implications, but too much for their own enlightenment of the opinions of those who are against it.

That is why the most urgent need is for a programme of public education. Governments are reluctant to take on this task for fear of exciting domestic opposition to further European integration. But is it not silly of them to hope that their own electors will joyfully sign on for the replacement of national currencies by a single European currency, for example, when the advantages of the change are so obscure, and the disadvantages (and inconveniences) so easily magnified and trumpeted? The difficulty is that the governments are unlikely to change. That is why the best course would be that the European Commission should take on the job of making sure that Europe as a whole understands what the European Union (for which Maastricht would legislate) is about. It would be a gigantic task, requiring that the Maastricht Treaty should be unpackaged into its components, each of which would have to be explained with care. But it is a job worth doing for its own sake. And quickly.

But that can be only a stop-gap. For the longer haul, there needs to be a way of making the proposed European Union more democratic than is now intended. It will not have escaped the attention of the officials in Brussels and the member governments that they are in danger of being overwhelmed by populism (represented by people as different as Mr Ross Perot from Texas, who would become the president of the United States, and Mr Vladimir Meciar, who would make Slovakia separate from Czechoslovakia). The convention that national governments, for the duration of their legal terms, embody the sovereign will of their electors is no longer widely acceptable. In any case, governments need not merely the dull acquiescence of their electors if they are to stay in office, but their active consent as well. The case for a more democratic European Union than that now foreseen is too urgent to be left for the review of Maastricht now planned for 1996.

\section{Sound embryo ruling}

\section{A Tennessee court accepts that an eight-cell blastomere is not advanced enough to be considered a person.}

How are the thousands of human embryos at the four-toeight cell stage of division, created in vitro from the eggs and sperm of men and women unable to conceive naturally and now frozen in liquid nitrogen in laboratories throughout the United States, to be disposed of? That question and others 